\title{
The Deconstructive Reading on Moll Flanders
}

\author{
Li Wang \\ School of Foreign Languages, Qingdao University of Science and Technology, Qingdao, China \\ Email: Wanglily523@163.com
}

\begin{abstract}
As the first female protagonist in Daniel Defoe's novels with first-person narrators, Moll Flanders is a highly ambiguous, problematic character. Emerging into the man-dominated, money-orientated society as an orphan from the lowest social class, she courageously defies her birth and eventually manages to achieve the self-designated identity of a gentlewoman. Centering on Moll's search for personal identity, which is undergone in extreme circumstances, this thesis discusses her three processes, which actually forms a circle to obtain gentlewoman-ship. From the territorialization of gentlewoman-ship at the beginning to the de-territorialization of gentlewoman-ship to the re-territorialization of gentlewoman-ship in the end, Moll has experienced a progress of subversion, rebellion and re-subversion. Therefore, we can find Defoe's hidden patriarchal discourse in the novel.
\end{abstract}

Index Terms-Moll Flanders, gentlewoman, territorialization, de-territorializationn, re-territorialization

Among Daniel Defoe's various works, Moll Flanders (1722) is his first novel, also the first one in the history of English literature, whose protagonist is a woman from the lowest social class. Moll the character is especially ambiguous, for she, though defiant and indomitable, is often confused about her own identity and even tends to fall into the muddle of self-deception.

Despite its great popularity upon publication, for a long time Moll Flanders has to find its readers in the lower classes. Respectable readers dismissed it as a secondary novel and found its vulgarity and profanity outrageously distasteful. Critics of Charles Lamb, William Hazlitt and twentieth-century literary criticism witnessed a drastic rise in the critical appreciation of Moll Flanders, such as Ian Watt, James Joyce, and Virginia Woolf.

I propose to approach Moll the character from her pursuit of identity, because it is undertaken in extreme circumstances and later it becomes the shaping force in her life-long struggle for survival. Through this line and Moll the character, I will prove Defoe's patriarchal discourse in this novel and show Moll in fact is an outsider and marginalized woman in the patriarchal society whether be a wife or whore or be a thief.

\section{TERRITORIALIZATION OF GENTLEWOMAN}

\section{A. Moll's Genteel Education}

Moll is the object of sexual code that is designated by the dominant society at the beginning of the novel. Moll has received the genteel education from the old woman as well as some leisured middle-class gentlewomen in Colchester since her early childhood. Compared with other orphans, Moll is probably a lucky dog, for she has been left in the care of a pious, sympathetic nurse, who brings her up "as Mannerly and as Genteelly" as if she has been " at the Dancing school", and later she has been patronized generously by some gentlewoman of the leisured middle-class. Thanks to the education stolen in the Colchester household, Moll is equipped with many wholesome talents for a gentlewoman who can be accepted by men and the dominant society: music, dancing, French, writing and agreeable speech. Defoe once advocated establishing colleges for women in order to train good women for society. All properties Moll possessed are almost Defoe's requirements for an "ideal woman". We have to admit that it is a proper and necessary thing to educate women but it will be a repressive one if the purpose of educating women is to breed them up to be suitable and serviceable. In addition, Defoe also mentioned, "the ladies might have all the freedom in the world within their own walls and yet no intriguing, no indecencies, nor scandalous affairs happen; and in order to this, the following customs and laws should be observed in the colleges..."According to such definition of such cultural codes, women is no more than the subsidiary of men. Furthermore, worries about intriguing scandalous affairs prove that the dominant society regards women "the other" as burden or even threatening of men "the self's". Only under the territorialization of laws and walls can men educate women better without changing their position in the society as "the other". Therefore all Moll's properties are the results of territorialization of the cultural codes of society which is dominated by men.

\section{B. Moll's First Three Marriages}

The territorialization of the cultural codes of dominant society is also represented by men's commercialization to women. Such right of commercialization is controlled by men. Moll, be a wife or whore, is commercialized or self-commercialized in order to satisfy men's demands. During this period, Moll is a typical woman designated by dominant society, genteel and subversive. She is so subversive that she would be even overwhelmed with gratitude by her fortune to be commercialized by men. Moll is surrounded by men "the center and self" at that times and subversive to the territorialization of the cultural codes of dominant society. With the discovery of the truth that her husband in 
Virginia in fact is her own brother, Moll decided to return London, thus ending her territorialized journey and beginning her de-territorialized journey.

\section{DE-TERRITORIALIZATIONN OF GENTLEWOMAN}

\section{A. Moll's Last Two Marriages}

Moll begins to destroy her former designated position by society and deconstruct the sexual codes. Her relation with men at this period proves her transformation. In the affairs with her Lancashire husband, Moll has erased the difference between men "the self" and women "the other". Moll and her Lancashire husband are the same from the nature and this marriage is a strategy of double deception. In this affairs, men/women regards the other side as "the self/the other" respectively, thus erasing the difference between men "the self" and women "the other". In the affairs with the clerk, Moll destroys the sexual codes and subverts it reversely to serve for herself. She has become the "bad woman" who feminizes men, that is, she has become the "the self" while men "the other". From the beginning of this marriage to the end of it, Moll is in positive and dominant position. From this marriage, Moll got what she wanted to get, that is, the economic security and quite life while clerk got what he wanted to get, that is, Moll-his ideal gentlewoman wife. As a matter of fact, this marriage is a covert commercialization. However, this time Moll is never the objective of it but the subjective of it.

\section{B. Moll's Thievery Career}

Since this period Moll's masculine property is more and more obvious. We are informed that she has a full range of costume, which would effectively turn her into a widow, a beggar, a well-dressed gentlewoman, a dignified Duchess and even a man. Underneath the various disguises, and surprisingly uninfluenced by her criminal experience, Moll, already a hardened, audacious thief, is characterized by the tendency to identify herself with the gentlewoman she has dreamed of becoming ever since her childhood. An interesting case is her experience of being mistaken for another thief in her affair with a mercer. During the whole process, Moll makes a fine picture of an indignant, innocent gentlewoman who is determined to defend her indignity and reputation. Far from viewing the capture of the poor thief as the ominous prediction of her own fate, she seems to perceive no similarity or affinity between her and that woman. It never occurs to her that all those ill words the journeyman lavishes serve her perfectly well; for, despite the fact she happens not to rob that shop at the specific spatio-temporal point, she is undoubtedly a thief here and elsewhere. She simply enjoys playing the role of a generous, benignant gentlewoman. However, the connotation of gentlewoman now has been changed totally. Moll is not the genteel and fragile gentlewoman who is asked to be able to play music, go dancing, speak French and agreeable speech any longer. She is a typical economic individualism who regards her economic benefit as life's prime want and uses her stolen property of being a gentlewoman as her disguise.

Parallel to Moll's identification, deceiving or self-deceptive, with a gentlewoman is her obvious de-feminization in this period. Though Ian Watt says she is "essentially masculine" in character and action, her female sexuality and genteel education enable her to present herself as a charming feminine figure under the male gaze in the past. Most men intimate with her enjoy her considerateness and carefulness in her tender care of the sick man of Bath. Her first and last husbands never question her wifehood and there is no mention of physical violence or rough disposition on Moll's part. However, her new criminal career marks a significant change and from then on, she becomes more masculine than feminine. Physically, her feminine sexuality has been considerably reduced, and when putting on men's clothes, she is almost indistinguishable from a man, to the extent that even her male fellow never suspects she "was not a Man". Psychologically, the thieving trade reduces Moll to a hardened egoist with no human feelings for others.

Liberated from the horror of going to service or doing housework, she not only earns her bread with her work but also accumulates an enormous sum of money to afford the expensive gentlewoman-ship. If her past identity as a wife or mistress presupposes dependence on the male others, her identity as a thief establishes her female self-dependence and makes Moll her own boss. More important, this disgraceful trade lays a solid economic foundation for her successful enterprise in the New World, without which Moll would never succeed in concluding this story in the capacity of a self-appointed penitential gentlewoman.

Being arrested to Newgate and transported to America with her Lancashire husband, Moll seems to deconstruct her identity of gentlewoman as well as the fixed sexual cultural codes.

\section{RE-TERRITORIALIZATION OF GENTLEWOMAN}

\section{A. Moll's Relationship with her Lancashire Husband in America}

Moll's masculine property reaches its climax in the afire with her Lancashire husband in America. Moll's marriage this time is beyond the patriarchal society though it is in the center of it. Moll once admitted that women, whether wife or whore, is men's servant and subversion. So she wants herself to be a pseudo- male or masculine female. Male/female in gender connotation and master/servant in cultural connotation are combined into one person now, thus destroying the designated signification of these two pairs of binary oppositions, erasing their cultural difference and only leaving the literal difference. Men (master) are women (servant); women (servant) are men (master). Moll's relation with her Lancashire husband can be the best evidence to prove this point. Moll not only didn't depend on men's gratitude and 
bestow but also hold her own right and benefit in this marriage. This masculine woman enjoys the right of controlling money that should belong to men's rights in family and plays the role of bringing bread for the family that also should belong to men's responsibility. Moll, in this marriage, is female (servant) as well as male (master); she represents female sexual codes (wife and the corresponding responsibility) as well as male sexual codes (economic security and master of family life). Furthermore, the harmonious relationship between Moll and her husband in this marriage also deconstructs the sexual difference between men and women.

We remember that before their separation near London, Moll once proposes to Jemy the plan of moving to Virginia, arguing, "a Man of application would presently lay a foundation for a family, and in a few years would raise an estate," but it turns out to be Moll who lays "a foundation for a family" and raises an estate. Jemy, characterized by his gentlemanly indolence and ignorance of plantation knowledge, prefers hunting in the woods while his wife is busy with the labor of managing their plantation. Compared with Jemy, who inherits his gentility but is unable to improve his impoverished gentleman-ship in his own, Moll, the self-made gentlewoman, is more worthy of that gentle title. To a large extent, it is the strong-willed Moll that restores his gentleman-ship both physically and spiritually. Sharing her fortune willingly with her husband, Moll takes special care to buy for him all kinds of luxurious things, such a swigs, swords, a fine saddle, and so on, delighting immensely in making him "appear a very fine Gentleman". Now we have to admit that Moll has reached the highest female independence or authority she has been struggling for in her life. Unlike the disguised gentlewoman who manipulates men for financial means and sacrifices live for expedient marriages, Moll eventually obtains a fixed identity as a self-made, self-reliant gentlewoman whose marriage, far from suggesting subordination to the patriarchal domination, conforms her female authority and capacities.

\section{B. Moll's Re-territorialization of Gentlewoman}

However, Moll's return to London in the end of the novel represents not only the ending of all her efforts to deconstruct the sexual and cultural codes but also the returning to the gentlewomen-ship designated by the dominant society at that times. Moll re-territorializes herself in the end of the novel after de-territorializes the sexual cultural codes, that is, she denies her efforts to deconstruct and erase the difference between men "the self" and women "the other" finally and subverts to the former position that designated by the dominant society: women is "the other" while men is "the self".

Distinguishing herself as an industrious tiller, experienced plantation manager and shrewd businesswoman, Moll sufficiently achieves the long-desired economic security. Possessing a flourishing plantation to ensure her economic prosperity, waited on by servants, equipped with enough comfortable things suitable for the gentle class in England, enjoying the company of a gentlemanly husband, Moll is justified in assuming the identity of a gentlewoman with ease.

According to Michael McKeon, in eighteenth-century English society which witnesses the mobility of social categories, the distinction between the gentility and other classes is no longer so strictly clear-cut, and "the traditional, qualitative criteria of honorific status were being definitely infiltrated by the quantitative criteria of socioeconomic class". A marginalized Dissenter who endeavored to integrate himself into society, Defoe attacked on more than one occasion "the idea of gentility residing in the blood" and, I think, ought not to question Moll's gentlewoman ship gained in America. And as further evidence, he gives a positive estimation of her success in the Preface: "Diligence and Application have their due Encouragement, even in the remotest Parts of the Worked, and that no case can be so slow, so despicable, or so empty of prospect, but that an unwearied Industry will go a great way to deliver us from it, will in time raise the meanest Creature to appear again in the Worked, and give him a new Cast for his Life". In her sixties, Moll, "who was Born in Newgate, and during a Life of continued Variety for Threescore Years, besides her Childhood, was Twelve year a Whore, five times a Wife (whereof once to her own Brother) Twelve Year a Thief, Eight Years a Transported Felon in Virginia," is finally given a chance to transform herself into a self-made gentlewoman, not only according to her standard, but also with the high probability of winning dominant society's approval.

Moll's final stay at London represents the ending of her geographical deconstruction, and her final realization of gentlewoman-ship not only according to her standard but also according to the dominant society's standard represents the ending of her psychological deconstruction. All things have been re-territorialized in the end and all Moll's efforts to erase the difference between men and women have been drowned by the great power of the dominant society. By a circle, Moll has come back to the starting point.

By the circle of Moll's pursuit to gentlewoman-ship and Moll's final re-territorialization to the dominant society, we can find Denial Defoe's hidden patriarchal discourse in the novel.

\section{REFERENCES}

[1] Chaber, Lois A. (1997). Matriarchal Mirror: Women and Capital in Moll Flanders. Critical Essays on Daniel Defoe, 181-201.

[2] Defoe, Daniel (1722). Moll Flanders. New York: Penguin Books.

[3] Defoe, Daniel (1910). On the Education of Women. New York: P. F. Collier \& Son.

[4] Gilbert, B.M. (1997). Postcolonial Theory. London \& New York: Verso.

[5] Healey, George H. (1955). The Letters of Daniel Defoe. London: Oxford University Press.

[6] Humm, Maggie (1994). A Reader's Guide to Contemporary Feminist Literary Criticism. New York: Harvester Wheatsheaf.

[7] Lewis, Reina \& Mills, Sara (2003). Feminist Postcolonial Theory. Edinburgh University Press.

[8] Novak, Maximillian E. (2001). Daniel Defoe. New York: Oxford University Press. 
[9] Pollak, Ellen (1997). Moll Flanders, Incest, and the Structure of Exchange. Critical Essays on Daniel Defoe, 202-217.

[10] Watt, Ian (1957). The Rise of the Novel. New York: Penguin Books.

Li Wang was born in Zibo, China in 1980. She received her M.A. degree in literature from Sichuan International Studies University, China in 2006.

She is currently a lecturer in the School of Foreign Languages, Qingdao University of Science and Technology, Qingdao, China. Her research interests include British and American literature.

Ms. Wang is a member of the Research Institute of Foreign Language Literature, Qingdao University of Science and Technology. 